ABDIMAS: Jurnal Pengabdian Masyarakat Universitas Merdeka Malang
Vol.6(1) February 2021, 18-26
L-ISSN: 2721-138X e-ISSN: 2548-7159
Uttp://jurnal.unmer.ac.id/index.php/jpkm

\title{
Penyuluhan Pencegahan Penularan COVID-19 di Lingkungan Kantor dan Pembuatan Lemongrass Coolant melalui Live Zoom
}

\author{
Nurul Azizah Choiriyah¹, Ika Mariani Ratna Devi², Sonia Anggun Sanjaya', Irra Chrisyanti Dewi', \\ Latifahtur Rahmah ${ }^{1}$ \\ ${ }^{1}$ Departemen Seni Kuliner, Akademi Kuliner dan Patiseri OTTIMMO Internasional \\ Jl. Telaga Golf TC 4 No 2-3, Citraland, Surabaya, 60217, Indonesia \\ ${ }^{2}$ Rumah Sakit Mitra Keluarga Surabaya \\ Jl. Satelit Indah II, Darmo Satelit, Surabaya, 60817, Indonesia
}

\section{ARTICLE INFO}

Received: 2020-10-02

Revised: 2020-12-05

Accepted: 2021-01-12

Keywords:

Beverage, Healthy protocol, Lemongrass, Prevent COVID-19 transmission

\section{ABSTRACT}

In the new normal era, many company leaders have restarted their business places for economic turnaround. The workplace has a major contribution to the spread of COVID-19 so efforts need to be made to break the chain of transmission. The workplace is a gathering place for a number of working populations and mobility is so high, work activities also lead to worker interaction. This community service aims to giving knowledge how to prevent COVID-19 transmission in office or industry and giving knowledge how to make beverage rich in antioxidant and vitamin $C$ to boost immune system. This community service consists of several steps including the preparation step which includes determining the time for the implementation of counseling, making material modules, making flyers and distributing flyers. The next step is the implementation step which includes the delivery of material, questions and answers regarding extension materials and demonstrations of making Lemongrass Coolant. The implementation step was done by zoom online media the final step of this activity is evaluation by filling the questions using Google Form. The participants were 41 people who work as lecturer, human resources department, undergraduate students, government employees, etc. Prevention of COVID-19 transmission is carried out by complying with the guidelines for the Decree of the Minister of Health of the Republic of Indonesia Number HK. 01.07/MENKES/328/2020. Making Lemongrass Coolant as a healthy drink rich in antioxidants as an immune booster does not require expensive ingredients and is also easy to manufacture. The participants joined in this community service with enthusiasm as evidenced by the many questions asked to the speakers.
\end{abstract}

(c) 2021 Published by University of Merdeka Malang. This is an open access article distributed under the CC BY-SA 4.0 license (https://creativecommons.org/licenses/by-sa/4.0/)

How to cite:

Choiriyah, N. A., Devi, I. M. R., Sanjaya, S. A., Dewi, I. C., \& Rahmah, L. (2021). Penyuluhan Pencegahan Penularan COVID-19 di Lingkungan Kantor dan Pembuatan Lemongrass Coolant melalui Live Zoom. Abdimas: Jurnal Pengabdian Masyarakat Universitas Merdeka Malang, 6(1), 18-26. https://doi.org/10.26905/abdimas.v6i1.4865 


\section{PENDAHULUAN}

Dengan adanya pandemi COVID-19 di dunia pada tahun 2020 ini, mengakibatkan pemerintah membatasi ruang gerak dalam melakukan aktivitas yang dilakukan bersama-sama. Kegiatan tri dharma perguruan tinggi yang melibatkan banyak peserta, salah satunya adalah pengabdian masyarakat. Agar perguruan tinggi terus dapat aktif melakukan kegiatan pengabdian masyarakat maka hal tersebut dapat dilakukan dengan menggunakan media online seperti zoom (Firmansyah et al., 2020). Media tersebut memungkinkan banyak partisipan untuk mengikuti kegiatan pengabdian masyarakat dari rumah. Narasumber juga dapat memberikan edukasi dengan efektif tanpa harus bertatap muka langsung dengan partisipan.

Pada era new normal, banyak pimpinan perusahaan sudah memulai kembali tempat usahanya untuk perputaran ekonomi. Tempat kerja memiliki kontribusi besar dalam penyebaran COVID-19 sehingga perlu dilakukan upaya untuk memutus rantai penularan. Industri, perusahaan atau kantor merupakan tempat berkumpulnya sejumlah populasi pekerja dan mobilitas begitu tinggi, aktifitas bekerja juga menyebabkan interaksi pekerja.

Mitra kegiatan pengabdian masyarakat secara daring ini adalah masyarakat umum. Masyarakat merasa khawatir pada pemberitaan mengenai peningkatan jumlah orang yang tertular Corona. Penyuluhan tentang COVID-19 dapat meningkatkan pengetahuan guna melakukan tindakan preventif secara mandiri dan promotif guna mencegah penularan COVID-19. Informasi yang benar bebas hoaks juga memberi manfaat agar pekerja tidak khawatir berlebihan yang berakibat pada penurunan imun (Wibowo, 2020).

Di era new normal ini, masyarakat pada umumnya juga perlu mengkonsumsi minuman berbahan antioksidan dan Vitamin C untuk meningkatkan sistem imun. Antioksidan banyak ditemukan pada berbagai jenis rempah di Indonesia. Sereh merupakan rempah yang mengandung antioksidan yang tinggi. Vitamin C dapat dijumpai pada produk lemon. Masyarakat perlu diedukasi bagaimana membuat minuman berantioksidan tinggi untuk meningkatkan sistem imun. Pada live zoom seri 1 juga akan dilakukan penyuluhan pembuatan minuman Lemongrass Coolant.

Dengan adanya live zoom "Pencegahan Penularan COVID-19 di Lingkungan Kantor" ini diharapkan dapat meminimalisir risiko dan dampak pandemi COVID-19 di tempat kerja khususnya perkantoran, dimana terdapat potensi penularan akibat berkumpulnya banyak orang dalam satu lokasi, Tujuan diselenggarakannya pengabdian masyarakat melalui live zoom ini diharapkan mampu memberikan pemahaman dalam pencegahan penularan COVID-19 di lingkungan kantor dan memberikan pengetahuan dalam membuat minuman kaya antioksidan dan vitamin $C$ untuk meningkatkan sistem imun tubuh.

\section{METODE}

Penyelenggaraan pengabdian masyarakat ini terdiri dari beberapa tahap diantaranya tahap persiapan yang meliputi penentuan waktu pelaksanaan penyuluhan, pembuatan modul materi, pembuatan flyer dan penyebaran flyer. Kegiatan ini terbuka bagi masyarakat umum. Penyebaran flyer dilakukan melalui WhatsApp grup, grup Telegram, grup Facebook yang beranggotakan dosen, mahasiswa bidang 
ABDIMAS: Jurnal Pengabdian Masyarakat Universitas Merdeka Malang

Volume 6, No. 1, February 2021: 18-26

kesehatan, dokter, aparatur sipil negara dalam Kementerian Pertanian, HRD, dan Tenaga kesehatan. Masyarakat yang berminat mendaftar maka mengisi formulir pendafataran melalui Google Form yang tertera pada flyer. Tahap selanjutnya adalah tahap pelaksanaan yang meliputi penyampaian materi dan tanya jawab mengenai materi penyuluhan. Materi yang disampaikan adalah pencegahan penularan COVID-19 di lingkungan kantor melalui manajemen tempat kerja dan manajemen pekerja. Materi yang lainnya yaitu penyuluhan pembuatan Lemongrass Coolant untuk meningkatkan imun tubuh. Tahap terakhir kegiatan ini adalah tahap evaluasi yang ditujukan kepada peserta live zoom. Tahap evaluasi dilakukan melalui media Google Form yang berisi mengenai pertanyaan-pertanyaan untuk menguji tingkat pemahaman peserta live zoom atas materi yang disampaikan.

\section{HASIL DAN PEMBAHASAN}

Kegiatan penyuluhan tentang pencegahan COVID-19 dilaksanakan pada tanggal 28 Agustus 2020 pukul 16.00 WIB sampai dengan 17.35 WIB. Acara bertempat di Akademi Kuliner dan Patiseri OTTIMMO Internasional. Kegiatan ini diikuti oleh 41 peserta yang berasal dari berbagai wilayah di Indonesia dan dari berbagai institusi pendidikan, rumah sakit dan perusahaan swasta di Indonesia. Sebaran pekerjaan peserta sebagai berikut mahasiswa, dokter, pekerja swasta, Aparatur Sipil Negara (ASN), dosen, dan Guru.

Pemaparan materi mengenai pencegahan COVID-19 di lingkungan kantor dilakukan oleh dokter Ika Mariani Ratna Devi, Sp.PD. Kementerian Kesehatan telah membuat panduan pencegahan dan pengendalian COVID-19 di tempat kerja perkantoran dan industri dalam mendukung keberlangsungan usaha pada situasi pandemi melalui Keputusan Menteri Kesehatan Republik Indonesia Nomor HK. 01.07/ MENKES/328/2020 (Kemenkes RI, 2020). Penentuan panduan tersebut dengan mempertimbangkan faktor pekerjaan, faktor di luar pekerjaan dan faktor komorbiditas. Jacovljevic \& Ostojic (2013) menyatakan bahwa komorbiditas adalah kondisi terjadi dua atau lebih penyakit secara bersamaan terlepas dari berkesinambungan atau tidaknya penyakit-penyakit tersebut.

Upaya pencegahan penularan COVID-19 di tempat kerja diantaranya Kebijakan Manajemen yang selalu memantau dan memperbaharui informasi tentang COVID-19. Pembaruan informasi COVID-19 di Indonesia selalu diperbarui melalui berita resmi di internet oleh pemerintah (Kementrian Kesehatan, 2020; Sufiyanto et al., 2020). Pimpinan perusahaan harus membentuk tim Satgas (Satuan Tugas) COVID19 yang terdiri dari pimpinan, karyawan menengah, dan karyawan tingkat bawah. Segala kasus yang dicurigai dan menyerupai COVID-19 seperti demam, batuk, pilek, radang tenggorokan, infeksi saluran pernafasan, dan sesak nafas harus dilaporkan untuk diperiksa oleh petugas kesehatan. Kasus positif COVID-19 di suatu kantor tidak boleh dianggap sebagai suatu hal yang memalukan, dijadikan bahan bullying atau dianggap stigma negatif. Aktivitas kantor apabila memungkinkan bekerja dilakukan dari rumah maka bisa diterapkan Work from Home (WFH). Protokol kesehatan sebelum masuk kantor yaitu pengukuran suhu badan menggunakan thermogun dan pengisian lembar pengukuran diri terhadap risiko COVID-19 untuk memastikan pekerja dalam kondisi sehat bebas dari virus.

Pada masa pandemi COVID-19 sebaiknya waktu kerja tidak terlalu panjang atau menghapuskan sistem lembur yang dapat mengakibatkan pekerja tidak memiliki waktu istirahat yang cukup. Kurang 
istirahat dapat menyebabkan sistem imun turun. Menghapus sistem kerja shift 3 (waktu kerja yang dimulai pada malam hingga pagi hari) merupakan hal bijaksana pada saat pandemi, Jika terpaksa ada sistem kerja shift maka perlu diatur agar yang bekerja dengan sistem tersebut adalah pekerja berusia kurang dari 50 tahun. Pekerja wajib menggunakan masker sejak perjalanan dari atau ke rumah, dan selama di kantor atau tempat kerja. Manajemen perusahaan perlu mengatur asupan zat gizi makanan yang diberikan, Pemberian buah-buahan yang kaya vitamin $C$ kepada pekerja seperti jeruk, lemon, dan jambu, untuk membantu mempertahankan daya tahan tubuh. Jika sulit memenuhi zat gizi pekerja dari buah-buahan, maka perusahaan dapat memberikan suplemen vitamin $\mathrm{C}$ kepada pekerja.

Fasilitas tempat kerja bebas dari penularan COVID-19 dilakukan dengan memperhatikan aspek hygiene dan sanitasi lingkungan, menyediakan sabun, sarana cuci tangan yang memadai, atau menyediakan hand sanitizer di tempat-tempat yang terjangkau. Manajemen perusahaan perlu menjaga penerapan physical distancing dalam semua aktifitas kerja, mensosialisasikan Gerakan Masyarakat Hidup Sehat (GERMAS) melalui Pola Hidup Sehat dan Perilaku Hidup Bersih dan Sehat (PHBS) di tempat kerja.

Bagi pekerja, hal-hal yang dapat dilakukan untuk berkontribusi terhadap pencegahan penularan COVID-19 di tempat kerja diantaranya selalu menerapkan Gerakan Masyarakat Hidup Sehat melalui prinsip hygiene dan sanitasi saat di rumah, sedang di perjalanan ke dan dari tempat kerja dan selama di tempat kerja. Saat perjalanan, selalu memastikan pekerja dalam kondisi sehat, jika ada gejala sakit atau dicurigai COVID-19 agar tetap istirahat di rumah, selalu memakai masker, mengusahakan tidak menggunakan kendaraan umum, jika harus menggunakan transportasi umum maka berusaha tidak sering menyentuh benda-benda yang ada disekitarnya dan physical distancing terus dijaga. Selama diperjalanan, hendaknya selalu membawa hand sanitizer, memilih pembayaran dengan e-money, menggunakan helm sendiri, menghindari mengucek mata, atau memegang-megang wajah dengan tangan.

Pekerja apabila baru sampai di tempat kerja segera mencuci tangan dengan sabun dan air mengalir selama 20 detik, memakai siku untuk menekan tombol lift dan membuka pintu, physical distancing di lift dengan posisi tidak berhadap-hadapan atau saling membelakangi, mengusahakan tidak sering menyentuh fasilitas umum di tempat kerja, membersihkan lingkungan kerja dengan desinfektan, physical distancing selama bekerja menjaga cahaya matahari dan aliran udara masuk ke ruangan kerja, tidak melakukan bersalaman dan menggunakan masker selama di tempat kerja. Masker kain sebaiknya yang terdiri dari 3 lapis dan mengganti masker tersebut setiap 4 jam sekali.

Ketika tiba di rumah, maka hal yang dilakukan pertama kali adalah mencuci tangan dengan sabun dan air mengalir, mandi dan berganti pakaian. Pekerja tidak bersentuhan dengan keluarga lainnya sebelum mandi dan mengganti baju. Pakaian dan masker yang digunakan untuk bekerja dicuci dengan deterjen. Masker sekali pakai harus dibuang dengan cara sebagai berikut robek dan basahi dengan desinfektan agar tidak menulari pengelola sampah. Handphone, kacamata, tas dapat dibersihkan dengan desinfektan atau alkohol 70\%. Tingkatkan daya tahan tubuh dengan beraktifitas fisik 30 menit perhari, konsumsi makanan beraneka ragam sehingga tercukupi gizinya, tidur cukup minimal 7 jam, berjemur di bawah sinar matahari pagi hari agar memperoleh vitamin D (Nimitphong \& Holick, 2013). 
ABDIMAS: Jurnal Pengabdian Masyarakat Universitas Merdeka Malang

Volume 6, No. 1, February 2021: 18-26

Setelah penyampaian materi maka dilaksanakan kegiatan tanya jawab antara peserta dengan narasumber. Peserta antusias dalam mengikuti kegiatan pengabdian masyarakat terlihat dari banyaknya pertanyaan yang diajukan. Gambar 1 menunjukkan foto saat live zoom 1 sedang berlangsung.
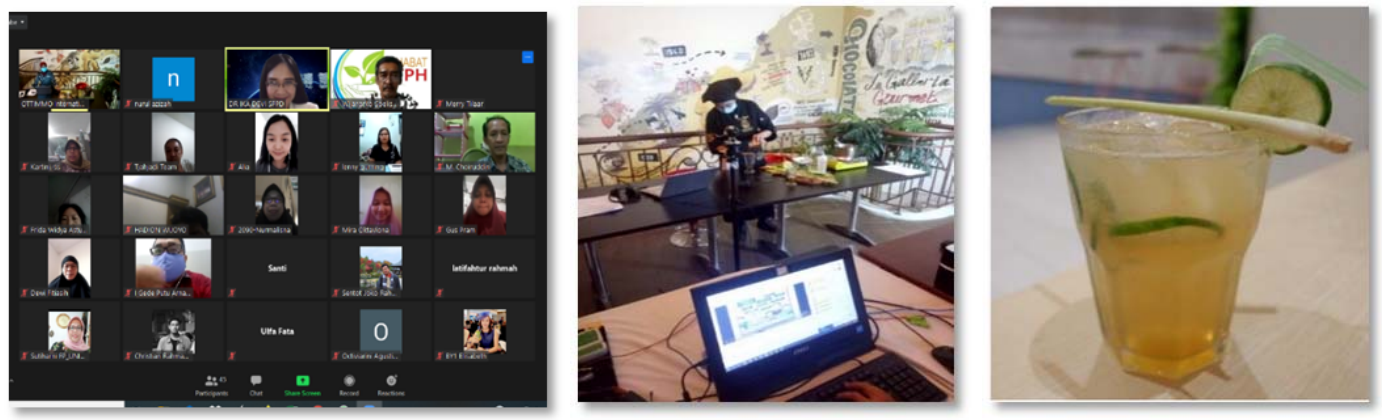

Gambar 1. Foto screenshoot layar saat live zoom berlangsung

Gambar 2. Penyuluhan pembuatan minuman Lemongrass Coolant

Gambar 3. Produk Lemongrass Coolant

Penyuluhan pembuatan Lemongrass Coolant dilaksanakan oleh salah satu tim pengabdi. Lemongrass Coolant terbuat dari jeruk nipis, sereh, gula batu dan mint. Gambar 2 menunjukkan foto penyuluhan pembuatan Lemongrass Coolant oleh Chef Sonia. Gambar 3 menunjukkan produk minuman Lemongrass Coolant. Gambar 4 menunjukkan tahapan proses pembuatan Lemongrass Coolant.

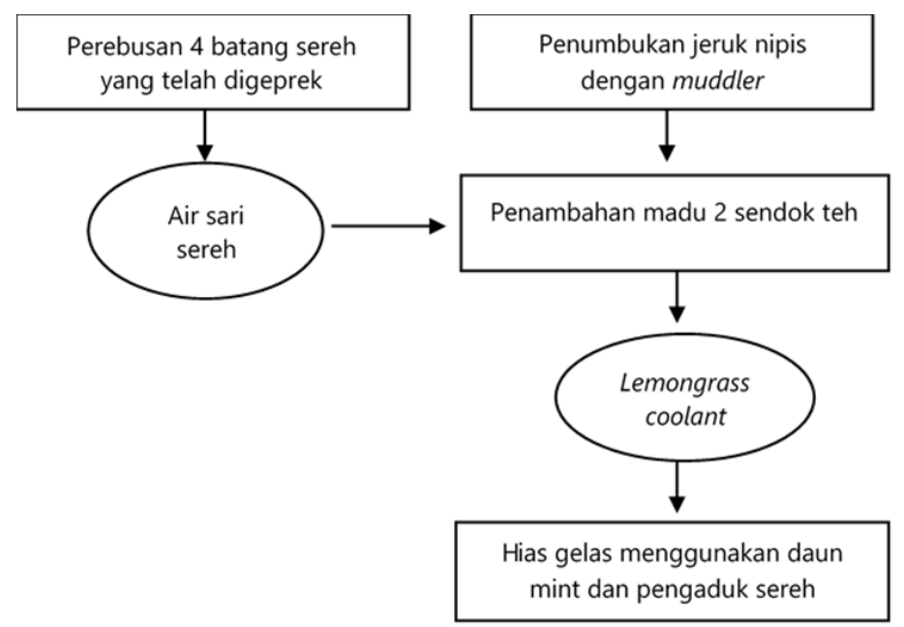

Gambar 4. Diagram alir pembuatan Lemongrass Coolant

Menurut Gambar 4, pembuatan Lemongrass Coolant adalah sebagai berikut persiapan jeruk nipis, air sereh, madu Asy-syifa, gula batu dan mint. Kemudian dilakukan penumbukan jeruk nipis dengan muddler, dan penuangan madu. Selanjutnya penambahan gula kemudian penuangan air sereh. Air sereh dibuat dengan merebus sereh dengan air hingga mendidih. Langkah terakhir yaitu hias gelas dengan jeruk nipis dan mint, pengaduk sereh. 
Lemongrass Coolant merupakan minuman yang dapat meningkatkan imun tubuh. Sereh memiliki aktifitas antioksidan sehingga dapat meningkatkan imun tubuh. Sereh juga memiliki sifat sebagai anti jamur dan antibakteri (Toungos, 2019). Ekstrak sereh terbukti secara efektif dapat mencegah kerusakan DNA (Balakrishnan et al., 2014).

Vitamin C sangat dibutuhkan pada masa pandemi COVID-19. Sebagai fakta, adanya kekurangan zat gizi vitamin C terjadi pada pasien COVID-19 (Grant et al., 2020). Vitamin C atau asam askorbat merupakan vitamin larut air dan tidak dapat disintesis oleh tubuh manusia. Vitamin $\mathrm{C}$ bersifat sebagai antioksidan. Vitamin C dikenal memiliki manfaat dalam mencegah penyakit infeksi dan infeksi virus (Shakoor et al., 2021).

Vitamin C diketahui dapat menurunkan sitokin proinflamasi seperti TNF-Alfa dan meningkatkan sitokin anti inflamasi seperti IL-10. Adanya peningkatan IL-10 dapat menekan IL-6 dan mengendalikan inflamasi pada pasien COVID-19 yang diberi suplementasi vitamin C (Shakoor et al., 2021). Bahan lemon yang digunakan dalam pembuatan Lemongrass Coolant merupakan bahan yang kaya akan vitamin $C$. Lemon dan minyak atsiri dari lemon telah terbukti dapat memperkuat sistem imun (Peterfalvi et al., 2019).

Pada pembuatan minuman Lemongrass Coolant ini menggunakan madu dan gula batu sebagai pemanis. Madu juga diketahui bersifat bakteriostatik dan bakterisidal. Madu dapat menghambat pertumbuhan bakteri Streptococcus beta hemoliticus Group A, bakteri penyebab faringitis. Sifat madu sebagai imunomodulator yaitu memicu makrofag untuk menghasilkan sitokin yang terlibat untuk perbaikan jaringan dan membunuh bakteri (Wineri et al., 2014) serta sebagai anti-inflamasi (Andayani, 2020). Madu juga memiliki sebagai antivirus dalam melawan virus penyebab influenza, rinovirus dan adenovirus (Kamilah, 2019). Antioksidan dalam madu diantaranya senyawa fenolik dan flavonoid yang berfungsi menghambat reaksi berantai radikal bebas (Tuksitha et al., 2018).

Peningkatan cita rasa (flavor) pada minuman Lemongrass Coolant dilakukan dengan penambahan daun pandan (Wijana \& Mulyadi, 2011). Lemongrass Coolant merupakan minuman kaya akan antioksidan yang cocok disajikan dalam keadaan hangat.

Tahap akhir dari kegiatan pengabdian masyarakat ini adalah evaluasi materi pengabdian masyarakat. Evalusi dilakukan dengan menggunakan media Google Form, peserta pengabdian masyarakat menjawab pertanyaan-pertanyaan yang berhubungan dengan materi yang disampaikan oleh narasumber. Hasil evaluasi pengabdian masyarakat ditunjukkan dengan Gambar 5.

Berdasarkan Gambar 5 diketahui bahwa setelah mengikuti kegiatan pengabdian masyarakat, peserta memiliki pengetahuan tentang pencegahan penularan COVID-19 di lingkungan kantor. Peserta yang menjawab soal P1 dengan benar sebanyak $80 \%$, peserta yang menjawab soal P2 dengan benar sebanyak 86\%, peserta yang menjawab soal P3, P4, P5 dan P7 dengan benar sebanyak 97\%, peserta yang menjawab P6 dengan benar sebanyak 77\%. Hal tersebut berarti bahwa peserta pengabdian masyarakat memiliki pengetahuan yang tinggi mengenai cara pencegahan penularan COVID-19 di lingkungan kantor karena pertanyaan P1 sampai dengan P7 dapat dijawab dengan benar oleh lebih dari $60 \%$ peserta. 
ABDIMAS: Jurnal Pengabdian Masyarakat Universitas Merdeka Malang Volume 6, No. 1, February 2021: 18-26

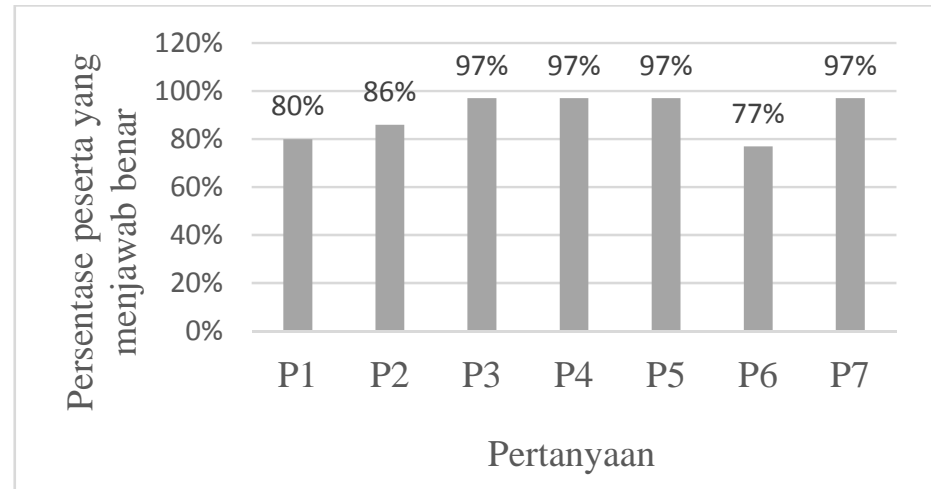

Gambar 5. Hasil evaluasi materi pengabdian masyarakat

Keterangan:

$\mathrm{P} 1=$ Pertanyaan mengenai karyawan dengan risiko tinggi terhadap COVID-19

P2 = Pertanyaan mengenai kebijakan yang dapat dilakukan untuk mencegah penularan COVID-19 di lingkungan kantor

P3 = Pertanyaan mengenai penggantian sistem absensi dari finger print menjadi barcode merupakan langkah operasional yang dapat dilakukan untuk mencegah penularan COVID-19

P4 = Pertanyaan mengenai penghentian perjalanan dinas karyawan ke luar kota dan luar negeri untuk mencegah penularan COVID-19

$\mathrm{P} 5=$ Pertanyaan mengenai penjagaan kualitas udara tempat kerja dengan mengoptimalkan sirkulasi udara dan sinar matahari masuk ruangan kerja, pembersihan filter AC merupakan saluh satu cara pencegahan penularan COVID-19

P6 = Pertanyaan mengenai Gerakan Masyarakat Sehat (Germas) di kantor yang dapat diterapkan untuk mencegah penularan COVID-19

P7 = Pertanyaan mengenai penggunaan helm sendiri saat naik kendaraan bermotor untuk mencegah penularan COVID-19

Kegiatan pengabdian masyarakat melalui media online perlu ditindaklanjuti pelaksanaannya misalnya dengan mengadakan seri-seri pengabdian masyarakat yang berbeda-beda agar para dosen dan peneliti tetap dapat aktif melakukan kegiatan yang bermanfaat bagi masyarakat.

\section{SIMPULAN DAN SARAN}

\section{Simpulan}

Kegiatan pengabdian masyarakat ini sangat bermanfaat bagi peserta sebagai pencegahan penularan COVID-19 di lingkungan tempat kerja. Pencegahan penularan COVID-19 dilakukan dengan mematuhi panduan Keputusan Menteri Kesehatan Republik Indonesia Nomor HK. 01.07/ MENKES/328/2020. Pembuatan Lemongrass Coolant sebagai minuman yang sehat dan kaya akan antioksidan sebagai immune booster tidak memerlukan bahan yang mahal serta pembuatannya juga 
Penyuluhan Pencegahan Penularan COVID-19 di Lingkungan Kantor dan Pembuatan Lemongrass Coolant melalui Live Zoom Nurul Azizah Choiriyah, Ika Mariani Ratna Devi, Sonia Anggun Sanjaya, Irra Chrisyanti Dewi, Latifahtur Rahmah

mudah. Peserta mengikuti pengabdian masyarakat ini dengan antusias terbukti dengan banyaknya pertanyaan yang ditujukan kepada narasumber.

\section{Saran}

Adanya kegiatan pengabdian masyarakat ini perlu adanya beberapa seri pelaksanaan yang berbeda. Seri-seri kegiatan ini diharapkan agar para dosen dan peneliti tetap aktif melakukan kegiatankegiatan lain yang dapat bermanfaat bagi mansyarakat.

\section{DAFTAR PUSTAKA}

Andayani, R. P. (2020). Madu sebagai terapi komplementer mengatasi diare pada anak balita. Jurnal Kesehatan Perintis (Perintis's Health Journal), 7(1), 64-68. https://doi.org/10.33653/jkp.v7i1.393

Balakrishnan, B., Paramasivam, S., \& Arulkumar, A. (2014). Evaluation of the lemongrass plant (Cymbopogon citratus) extracted in different solvents for antioxidant and antibacterial activity against human pathogens. Asian Pacific Journal of Tropical Disease, 4(1), 134-139. https://doi.org/10.1016/S2222-1808(14)60428-X

Firmansyah, A., Qadri, R. A., \& Arham, A. (2020). Pelatihan melalui Web Seminar terkait Publikasi Artikel untuk Menembus Jurnal Sinta 2 dan Scopus. Abdimas: Jurnal Pengabdian Masyarakat Universitas Merdeka Malang, 5(2), 131-138. https://doi.org/10.26905/abdimas.v5i2.4244

Grant, W. B., Lahore, H., McDonnell, S. L., Baggerly, C. A., French, C. B., Aliano, J. L., \& Bhattoa, H. P. (2020). Evidence that vitamin D supplementation could reduce risk of influenza and COVID-19 infections and deaths. Nutrients, 12(4), 1-19. https://doi.org/10.3390/nu12040988

Jacovljevic, M., \& Ostojic, L. (2013). Comorbidity and multimorbidity in medicine today: Challenges and opportunities for bringing separated branches of medicine closer to each other. Psychiatr Danub, 1, 18-28.

Kamilah, M. F. (2019). Analisis Edukasi Penggunaan Madu Sebagai Obat Komplementer pada Pharyngitis. https://doi.org/10.31227/osf.io/7mj92

Kemenkes RI. (2020). Keputusan menteri kesehatan republik indonesia nomor hk.01.07/ menkes/328/2020 tentang panduan pencegahan dan pengendalian. Keputusan Menteri Kesehatan Republik Indonesia Nomor Hk.01.07/Menkes/413/2020 Tentang Pedoman Pencegahan Dan Pengendalian Coronavirus Disease 2019 (COVID-19), 2019.

Kementrian Kesehatan. (2020). Info infeksi emerging Kementerian Kesehatan RI. Kemenkes. https:// infeksiemerging.kemkes.go.id/

Nimitphong, H., \& Holick, M. F. (2013). Vitamin D status and sun exposure in Southeast Asia. In Dermato-Endocrinology (Vol. 5, Issue 1, pp. 34-37). https://doi.org/10.4161/derm.24054

Peterfalvi, A., Miko, E., Nagy, T., Reger, B., Simon, D., Miseta, A., Czéh, B., \& Szereday, L. (2019). Much more than a pleasant scent: A review on essential oils supporting the immune system. Molecules, 24(24), 1-16. https://doi.org/10.3390/molecules24244530 
ABDIMAS: Jurnal Pengabdian Masyarakat Universitas Merdeka Malang Volume 6, No. 1, February 2021: 18-26

Shakoor, H., Feehan, J., Al Dhaheri, A. S., Ali, H. I., Platat, C., Ismail, L. C., Apostolopoulos, V., \& Stojanovska, L. (2021). Immune-boosting role of vitamins D, C, E, zinc, selenium and omega-3 fatty acids: Could they help against COVID-19? Maturitas, 143, 1-9.

https://doi.org/10.1016/j.maturitas.2020.08.003

Sufiyanto, S., Yuniarti, S., \& Andrijono, D. (2020). Sosialisasi dan edukasi penilaian mandiri terhadap risiko penularan COVID-19 melalui InaRISK Personal. Abdimas: Jurnal Pengabdian Masyarakat Universitas Merdeka Malang, 5(3), 209-219. https://doi.org/10.26905/abdimas.v5i3.5004

Toungos, M. D. (2019). Lemongrass (Cymbopogon, L. spreng ) valuable grass but underutilized In Northern Nigeria. International Journal of Innovative Food, Nutrition and Sustainable Agriculture, $7(2), 6-14$.

Tuksitha, L., Chen, Y. L. S., Chen, Y. L., Wong, K. Y., \& Peng, C. C. (2018). Antioxidant and antibacterial capacity of stingless bee honey from Borneo (Sarawak). Journal of Asia-Pacific Entomology, 21(2), 563-570. https://doi.org/10.1016/j.aspen.2018.03.007

Wibowo, S. B. (2020). Tips Agar Virus Corona Tidak Mempengaruhi Kesehatan Mental Universitas Muhammadiyah Metro. https://ummetro.ac.id/tips-agar-virus-corona-tidak-mempengaruhikesehatan-mental/

Wijana, S., \& Mulyadi, A. F. (2011). Pengaruh penambahan konsentrasi daun pandan wangi (Pandanus amarillifolius roxb.) dan lama pemanasannya pada pembuatan sirup gula kelapa aroma pandan (kajian konsentrasi dan lama pemanasan daun pandan wangi) [Thesis]. Universitas Brawijaya Malang.

Wineri, E., Rasyid, R., \& Alioes, Y. (2014). Perbandingan daya hambat madu alami dengan madu kemasan secara in vitro terhadap Streptococcus beta hemoliticus Group A sebagai penyebab faringitis. Jurnal Kesehatan Andalas, 3(3), 376-380. https://doi.org/10.25077/jka.v3i3.140 